\title{
Perkembangan Pertunjukan Salawat Dulang di Minangkabau
}

\author{
Syafniati, Firdaus, Amran \\ Program Studi Seni Karawitan, Fakultas Seni Pertunjukan \\ Institut Seni Indonesia (ISI) Padangpanjang \\ Jalan Bahder Johan Padangpanjang 27128 \\ Email: syafniaticapcay@gmail.com
}

\begin{abstract}
The purpose of this study is to examine factors driving to the development and changes in salawat dulang, which was initially functioned as a means for dakwah. Salawat dulang is one of traditional Islamic arts in the form of singing accompanied by dulang punch as instruments. The lyrics in salawat dulang contain Islamic teachings including the remembrance of Allah Swt. and the praise to the prophet Muhammad saw. Based on the current situation there are developments and changes in salawat dulang, which is resulted in changes of function from performing dakwah to performing art. This qualitative research uses a descriptive analysis method with anthropology, sociology, and aesthetic approaches. Data collection techniques are carried out in several ways including observation, interviews, and documentation. The results found that the development and changes in salawat dulang are caused by both internal and external factors, without changing existing values. Changes occurred in the presentation of vocals adopted from modern and popular songs following the tastes of the audience.
\end{abstract}

Keywords: salawat dulang, traditional performing art, changes and development

\begin{abstract}
ABSTRAK
Tujuan penelitian adalah untuk membahas perkembangan dan perubahan pertunjukan salawat dulang yang pada awalnya berfungsi sebagai sarana dakwah. Salawat dulang merupakan kesenian tradional islami, berupa nyanyian yang diiringi oleh pukulan dulang sebagai instrumen pengiring. Syair yang disampaikan berisikan ajaran Islam, berupa zikir kepada Allah Swt. dan pujian kepada nabi Muhammad saw. Seiring perkembangan zaman, salawat dulang mengalami pergeseran fungsi dari ritual menjadi seni pertunjukan. Penelitian kualitatif menggunakan metode deskriptif analisis dengan pendekatan antropologi, sosiologi, dan estetika. Pengumpulan data dilakukan melalui observasi, wawancara, dan dokumentasi. Hasil penelitian menemukan bahwa perkembangan dan perubahan salawat dulang dipengaruhi oleh faktor internal dan eksternal, dengan tidak mengubah nilai-nilai tradisi yang ada. Perubahan terjadi pada penyajian vokal yang mengadopsi lagu-lagu modern dan populer, menyesuaikan dengan selera masyarakat pendukungnya.
\end{abstract}

Kata kunci: salawat dulang, seni pertunjukan, perubahan dan perkembangan 


\section{PENDAHULUAN}

Salawat dulang adalah salah satu kesenian tradisional bernuansa islami, yang hidup dan berkembang dalam masyarakat Minangkabau di Provinsi Sumatera Barat. Kesenian ini digemari oleh seluruh lapisan masyarakat, karena hampir di setiap pelosok dari desa hingga ke kota di wilayah Minangkabau, masyarakat mengenal salawaik dulang (salawaik talam) (Firdaus, 2013: 3). Pada awalnya, pertunjukan ini digunakan untuk sarana dakwah. Kemudian, seni ini mengalami perubahan menjadi seni pertunjukan.

Kesenian salawat dulang disajikan dalam bentuk vokal, syairnya dilantunkan dengan bahasa Minangkabau. Adapun teks (syair) selawat dulang berisikan ajaran agama Islam yang mengandung nilai-nilai ketauhidan terhadap Allah Swt. dan Nabi Muhammad saw., sebagaimana yang tertera dalam Alquran dan hadis Nabi.

Salawat dulang disajikan oleh dua kelompok penyaji, masing-masing kelompok terdiri dari dua orang laki-laki, menyajikan salawat dulang dengan posisi duduk di atas kasur yang telah disediakan oleh panitia pelaksana. Pelaksanaan salawat dulang dilakukan pada malam hari. Biasanya, dimulai pukul 21.00 WIB dan diakhiri menjelang subuh sekira pukul 4.00 WIB.

Masing-masing kelompok tampil secara bergantian dengan durasi 50 sampai 60 menit. Penyajian salawat dulang dilaksanakan dengan cara bernyanyi sambil memukul dulang. Bunyi dari pukulan dulang berfungsi sebagai instrumen pengiring nyanyian salawat dulang, sekaligus sebagai pengatur tempo yang dinamik. Dulang dipukul dengan tangan kanan, sedangkan tangan kiri memegang dulang. Untuk satu kali pertunjukan yang ditampilkan oleh satu grup disebut dengan istilah satu tanggak.

Pertunjukan satu tanggak sama dengan satu kali putaran yang terdiri dari susunan lagu-lagu yang ditampilkan secara utuh, dimulai dari lagu 'imbauan' dilanjutkan dengan lagu 'khotbah', lagu 'batang', yamolai, dan lagu cancang. Semua lagu tersebut merupakan struktur yang harus disajikan dalam satu kali putaran. Masing-masing grup dalam satu malam mendapat giliran pertunjukan sekira tiga atau empat kali putaran.

Kehadiran kesenian salawat dulang bermula dari penyebaran agama Islam oleh pedagang Islam dari Arab, India, Cina, dan lain sebagainya, ke berbagai daerah di Indonesia. Salah satu wilayah yang didatangi para pedagang tersebut adalah Sumatera bagian utara, hingga sekarang agama Islam telah menyebar ke seluruh wilayah di Nusantara (Ricklefs, 1995: 4).

Penyebaran Islam ini lama kelamaan sampai ke Minangkabau yang ditandai dengan hadirnya seorang murid Syekh Abdurrauf yang berasal dari Aceh, yaitu Syekh Burhanuddin, yang kemudian menjadi ulama besar di Minangkabau. Syekh Burhanuddin mengajarkan agama Islam kepada murid-muridnya, yang dikenal dengan jemaah tarekat Satariyah. Berkat upaya dakwah Syekh Burhanuddin beserta jemaah tarekat Satariyah ini, maka agama Islam berkembang sampai ke berbagai pelosok di Minangkabau (Yunus 1985: 18-19).

Syekh Burhanuddin menyebarkan Islam pertama kali di Minangkabau pada abad ke-17 di Ulakan Pariaman. Di antara murid-murid Syeh Burhanuddin, ada tiga orang tokoh ulama di Nagari Malalo Kabupaten Tanah Datar Provinsi Sumatera Barat, bernama Tuanku Musajik, J. Tuanku Lima Puluh, dan Katik Rajo.

Adapun ajaran Islam yang diajarkan oleh Syekh Burhanuddin tersebut adalah tentang ketauhidan terhadap Allah Swt. dengan mempelajari sifat-sifat Allah yang dikenal dengan sifat dua puluh. Selanjutnya, diajarkan juga ilmu tasawuf yang mempelajari tentang asal tubuh, dan nyawa (roh) manusia. Metode pengajaran yang 
disampaikan Syekh Burhanuddin tersebut dikenal dengan ajaran tarekat (Sriwulan, 1999: 5).

Tarekat adalah salah satu bentuk pelaksanaan ajaran tasawuf, yang berarti jalan atau petunjuk dalam melakukan ibadah sesuai dengan aturan dalam syariat, dengan cara belajar mendekatkan diri dengan memperbanyak zikir kepada Allah Swt. (Atjeh, 1963: 121).

Dewasa ini, kesenian salawat dulang sering dipertunjukkan untuk hiburan, memeriahkan berbagai kegiatan masyarakat, seperti dalam rangka peringatan Maulid Nabi Muhammad saw., Isra Mikraj, Idulfitri, Iduladha, tahun baru Hijriah, khataman Alquran, dan sebagainya. Biasanya, masyarakat mendatangkan dua grup seniman salawat dulang untuk menampilkan kebolehannya dalam suatu pertunjukan salawat dulang.

Seiring perkembangan zaman, salawat dulang sudah bergeser fungsinya, yang semula sebagai sarana dakwah dalam menyampaikan syiar agama Islam, kemudian berubah menjadi hiburan dan tontonan, sebagai seni pertunjukan. Perubahan merupakan fenomena sosial yang wajar, karena setiap manusia mempunyai kepentingan yang tidak terbatas. Perubahan yang terjadi bisa merupakan kemajuan atau kemunduran (Syani, 1995: 162). Terjadinya perkembangan pada salawat dulang merupakan suatu proses yang tidak terelakkan, seiring perkembangan umat manusia karena adanya komunikasi yang semakin terbuka. Esten (1993: 13) menjelaskan bahwa apabila suatu kesenian mau tetap hidup dalam kehidupan masyarakat, harus sanggup menghadapi perubahan-perubahan, maka kemungkinan akan terjadinya pergeseran nilai-nilai tradisi yang nantinya ditemukan suatu bentuk baru.

Terjadinya perubahan pada penyajian salawat dulang, tidak berpengaruh terhadap nilai-nilai tradisi yang melekat pada pertunjukan salawat dulang tersebut. Tetapi, perubahan tersebut merupakan keberlanjutan dari bentuk pertunjukan yang sudah ada. Kesenian salawat dulang semakin mendapat perhatian dari masyarakatnya.

Berdasarkan uraian di atas, masalah yang akan dibahas dalam tulisan ini difokuskan kepada bentuk penyajian sebelum perkembangan dan bentuk penyajian setelah perkembangan pada pertunjukan salawat dulang, dan faktor apa yang menjadi penyebab perkembangan pertunjukan tersebut.

\section{METODE}

Untuk mengetahui perkembangan dan perubahan salawat dulang, peneliti melakukan pngumpulan data penelitian melalui sumber data tertulis dan sumber data lisan. Sumber data tertulis berupa buku, jurnal, ensiklopedi, kamus, brosur, surat kabar, dan surat-surat berharga lainnya, arsip, serta dokumen. Selain itu, dilakukan observasi, wawancara, dan dokumentasi. Semua data tersebut dikelompokkan dan dianalisis sesuai dengan tujuan penelitian (Soedarsono, 2001: 128).

Pengumpulan data di lapangan dilakukan secara kontekstual dan tekstual tentang seni pertunjukan peneliti menggunakan penelitian kualitatif dengan metode deskriptif. Pengamatan dilakukan terhadap jalannya pertunjukan, pendukung, baik sebagai seniman, dan juga penikmat. Selanjutnya, dilakukan pengamatan terhadap perlengkapan pertunjukan, perilaku pemain, ataupun penonton, dan situasi sosial (Moleong, 1991: 3).

Berdasarkan data di lapangan, peneliti mengamati pertunjukan salawat dulang dengan melakukan observasi, wawancara, dan pengambilan foto untuk dokumentasi. Dalam hal ini, penelitian dilakukan di tiga tempat pertunjukan salawat dulang, yaitu Nagari Lintau Kabupaten Tanah Datar, Solok, dan Kayu Tanam Kabupaten Padang Pariaman. 
Wawancara dilakukan terhadap seniman, penonton, tokoh masyarakat adat dan tokoh agama, yang banyak memahami tentang latar belakang kesenian salawat dulang, baik sebagai pencinta seni salawat dulang maupun penonton. Adapun seniman yang menjadi objek penelitian adalah grup Arjuna Minang, Sinar Barapi, Langkisau, serta grup Jet Angkasa.

Analisis data dilakukan secara tekstual dan kontekstual. Dari sudut tekstual, berkaitan dengan repertoar lagu-lagu dalam penyajian salawat dulang, meliputi jenis lagu yang terdapat dalam pertunjukan, dan juga teks nyanyian, melodi, srtruktur pertunjukan, dan tempat pertunjukan. Sementara itu, dari sisi kontekstual yang berhubungan dengan perkembangan dan perubahan dalam pertunjukan, serta fungsi musik salawat dulang dalam masyarakat.

Analisis data dilakukan dengan menggunakan teori perkembangan dan perubahan, sesuai dengan tujuan penelitian.

\section{HASIL DAN PEMBAHASAN}

\section{Bentuk Pertunjukan Salawat Dulang Sebelum Berkembang}

Bentuk pertunjukan salawat dulang ini bermula dari salah satu metode pendidikan yang digunakan oleh salah seorang murid Syekh Burhanuddin di Pariaman, yaitu J. Tuanku Lima Puluh. Metode pendidikan yang digunakan tersebut berupa ceramah tentang ajaran Islam, mengajar membaca Alquran, dan mengajak masyarakat untuk berbuat baik terhadap sesama, sesuai dengan yang dicontohkan oleh Nabi Muhammad saw. Metode pengajaran tersebut berasal dari pendidikan dalam ilmu tarekat (Sri Wulan 1999: 78).

Sebagai kelanjutan metode pembelajaran ilmu agama tersebut, J. Tuanku Lima Puluh melakukan metode baru untuk mengajak masyarakat belajar tentang ajaran Islam, yaitu dengan melagukan bacaan-bacaan selawat yang berisikan salam dan kesejahte- raan terhadap Nabi Muhammad saw., sifat dua puluh, masalah tubuh, nyawa, kisah kehidupan Nabi Muhammad saw., serta sejarah-sejarah Islam di zaman nabi. Kegiatan dakwah Islam yang demikian lazim disebut dengan hikayat, atau di Minangkabau dikenal dengan istilah bakayaik (1999: 90). Hikayat, menurut kamus Bahasa Indonesia, adalah karya sastra lama berbentuk prosa yang berisi cerita (https://kbbi.web. id/hikayat.html).

Metode pendidikan dakwah yang dilakukan oleh J. Tuanku Lima Puluh ini yaitu dengan cara melafalkan bacaan zikir dan selawat nabi yang berasal dari ilmu tarekat. Ajaran tarekat berisikan tentang asal tubuh, nyawa, dan makrifat tentang Allah. Semuanya tertera dalam Alquran dan juga kisah para nabi, mulai Nabi Adam sampai Nabi Muhammad saw. Semua ajaran tersebut dihafalkan oleh murid Tuanku J. Lima Puluh bersama-sama sambil dilagukan. Sistem penghafalan itu juga mengalami perkembangan menjadi penyajian teks secara spontan, dengan tidak hanya menyampaikan masalah agama saja. Akan tetapi, juga masalah yang berkembang di tengah-tengah masyarakat, seperti masalah adat istiadat, sosial budaya, dan sebagainya. Hal tersebut merupakan modal yang paling menarik dalam pertandingan salawat dulang (Firdaus, 2013: 82).

Kegiatan dakwah tersebut kemudian dikenal dengan istilah bakayaik (hikayat). Lama kelamaan masyarakat tertarik mendengarkan kegiatan bakayaik ini. Kemudian, semakin hari bertambah banyak murid J. Tuanku Lima Puluh untuk mempelajari ajaran Islam. Dengan bakayaik ini, muncullah bentuk seni suara dengan teks-teks yang dilagukan yang berisi cerita, seperti contoh berikut.

Nyawa jo kulimah mano nan tuo

Manuruik sajarah nan kami terimo

Lah nyato sajo kulimahnan tuo

"Alastu birobbikum" itu bunyinyo

Adapun takalo dahulu maso 
Sabutir alam balun lai ado

Balun balangik babumi nangko

Malainkan Allah seorang sajo

Badiri Allah dengan sendirinyo

Kun fayakumnan Tuhan ucap

Sabanta itu nur terkilat

Sudah terjadi nur Muhammad

Cemerlangnyo nurTuhan Muhammad

Terjemahan:

(Nyawa dengan kalimat mana yang tua, menurut sejarah yang kami terima, tentu saja kalimat yang tua "Alastu birobikum" itu alasannya, adapun waktu dahulu masa. Sebutir alam belum ada, belum ada sorga belum ada neraka, belum ada langit, belum ada bumi nyata, selain Tuhan sendiri saja. Berdiri Allah dengan sendirinya, kun fayakun yang Tuhan ucap, sebentar itu Nur terkilat, sudah terjadi Nur Muhammad, cemerlangnya Nur Tuhan Muhammad).

Selain sifat Tuhan, diajarkan juga cara memahami hakekat hidup, asal usul tubuh, roh (nyawa), dan sebagainya. Contoh teks tentang roh (nyawa), sebagai berikut.

Asalnyo nyawa lai kami baco

Ndak nyato tumbuahnyo dimano bijo

Di asalnyo nyawa kok tidak nyato

Karanonyo nyawa ado dikito

Asalnyo nyawa tidak jali

Percuma mambaco Innalillahi

Kemudian itu Wainna Illahi

Dengan Roji'unna pulo sakali

Nak kami sabuik asalnyo nyawa

Di dalam quran ayatnyo ado

Ayat ayat saratuih tujuh puluah duo

Di surek a'raf handaklah baco

Tetapi Tuhan bakuaso sungguah

Sagalo paluah kalua di tubuah

Aratinyo aruah nyawa di tubuah

Adopun sagalo alam arwah

Alamnyo halus sucinyo jilah

Dikarando kaco tampek bermada

Dikaliliangnyo Nur bahimpun sudah

Terjemahan:

(Asal nyawa yang kami baca, supaya nyata di mana tumbuhnya, asalnya nyawa jika tidak nyata, karena nyawa ada pada kita, jika asalnya nyawa tidak jelas, percuma membaca Innalillahi, wainna ilaihi dengan raajiu'unnya. Jika kami jelaskan asalnya nyawa, dalam Alquran ayatnya ada, ayat seratus tujuh puluh tiga, surat Al-A'raf hendak dibaca, Tuhan berkuasa sungguh, segala keringat keluar dari tubuh, artinya arwah nyawa di tubuh, adapun segala alam arwah, alamnya halus suci dan bersih, ber- tempat dalam keranda kaca yang dikelilingi Nur yang sudah berkumpul).

\section{Perkembangan Pertunjukan Salawat Dulang}

Sampai saat ini, bakayaik menjadi pertunjukan kesenian yang diiringi dengan instrumen salawat dulang, dan ada juga dengan alat musik rebana. Syair ajaran Islam tersebut dinyanyikan sambil memukul dulang sebagai instrumen pengiring. Syair yang dilantunkan juga telah dikembangkan.

Pada akhirnya, tradisi bakayaik yang disajikan oleh J. Tuanku Lima Puluh menjadi populer sebagai salah satu seni bernuansa Islam. Sampai sekarang, seni bakayaik ini masih terdapat di daerah dalam wilayah Minangkabau, seperti Tanah Datar, Lima Puluh Kota, dan Agam. Dalam perkembangannya, bakayaik dilakukan oleh dua orang secara bersahut-sahutan sambil memukul dulang. Sejak itu, kesenian ini dikenal dengan salawaik dulang.

Di tengah perkembangan teknologi dan informasi sekarang ini, seni pertunjukan tradisional masyarakat Minangkabau mengalami perkembangan, baik dari segi pertunjukan maupun penyebarannya. Perkembangan ilmu pengetahuan dan teknologi modern yang pesat juga berpengaruh terhadap pandangan hidup orang dalam melanjutkan tradisi. Untukitu, budaya suatu kesenian yang hidup, tumbuh, dan berkembang pada kelompok masyarakat telah melahirkan kesenian tradisi. (https//marsyadinda.wordpress.com. diakses 28 April 2017).

Sejalan perkembangan budaya, maka kesenian salawat dulang di tengah-tengah kehidupan mayarakat mengalami perubahan. Pertunjukan salawat dulang biasa dilakukan sehubungan dengan berbagai peringatan hari-hari besar agama Islam, seperti telah disebutkan di atas. Dewasa ini, pertunjukan salawat dulang dipertunjukan pada kegiatan lain yang ada dalam masyarakat, yaitu pada pesta perkawinan, khataman Alquran, perayaan khitanan, dan sebagainya. 


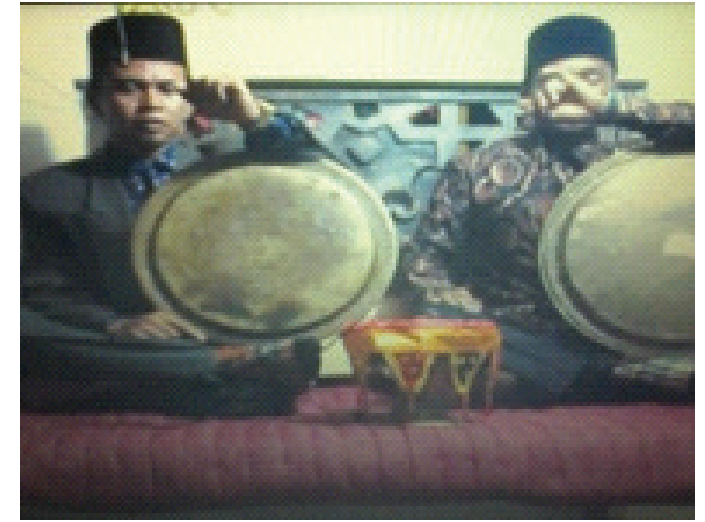

Gambar 1. Teknik duduk tukang salawat dulang grup Jet Angkasa (Sumber: Syafniati, 2018)

Seperti dikemukakan di atas, pertunjukan salawat dulang disajikan dengan posisi duduk bersila di atas kasur. Masing-masing penyaji bernyanyi sambil memukul $d u$ lang sebagai instrumen. Instrumen dulang diletakkan di atas telapak kaki kanan yang diikat dengan kain sarung agar tidak sakit kena pinggir dulang. Tangan kiri memegang tepi dulang, sedangkan tangan kanan memukul dulang sebagai mengiringi irama lagu salawat dulang (lihat gambar 1).

Dalam struktur pertunjukan salawat $d u$ lang berisikan dua bagian. Bagian pertama, berisikan pengajian tentang ajaran agama Islam yang berdasarkan Alquran dan hadis berupa teks tertulis yang tidak bisa dimodifikasi oleh tukang selawat. Teks tersebut dapat dilihat pada penyajian mulai dari lagu imbauan khotbah, khotbah, lagu batang, dan yamolai. Bagian kedua adalah bagian yang dapat dimodifikasi pada saat pertunjukan berlangsung, yaitu bagian hiburan yang terdapat pada lagu Cancang. Masing-masing grup menyajikan lagu sesuai dengan struktur pertunjukannya dengan berbagai irama lagu yang indah, sesuai dengan teks salawat dulang .

a. Pertunjukan Salawat Dulang Berupa Pengajian.

1. Imbauan Khotbah

Bagian imbauan khotbah merupakan salah satu bagian yang ditampilkan pada awal pertunjukan salawat dulang. Imbauan khotbah berupa pemberitahuan kepada para penonton bahwa pertunjukan telah dimulai. Melodi dan teks imbauan khotbah adalah sebagai berikut.

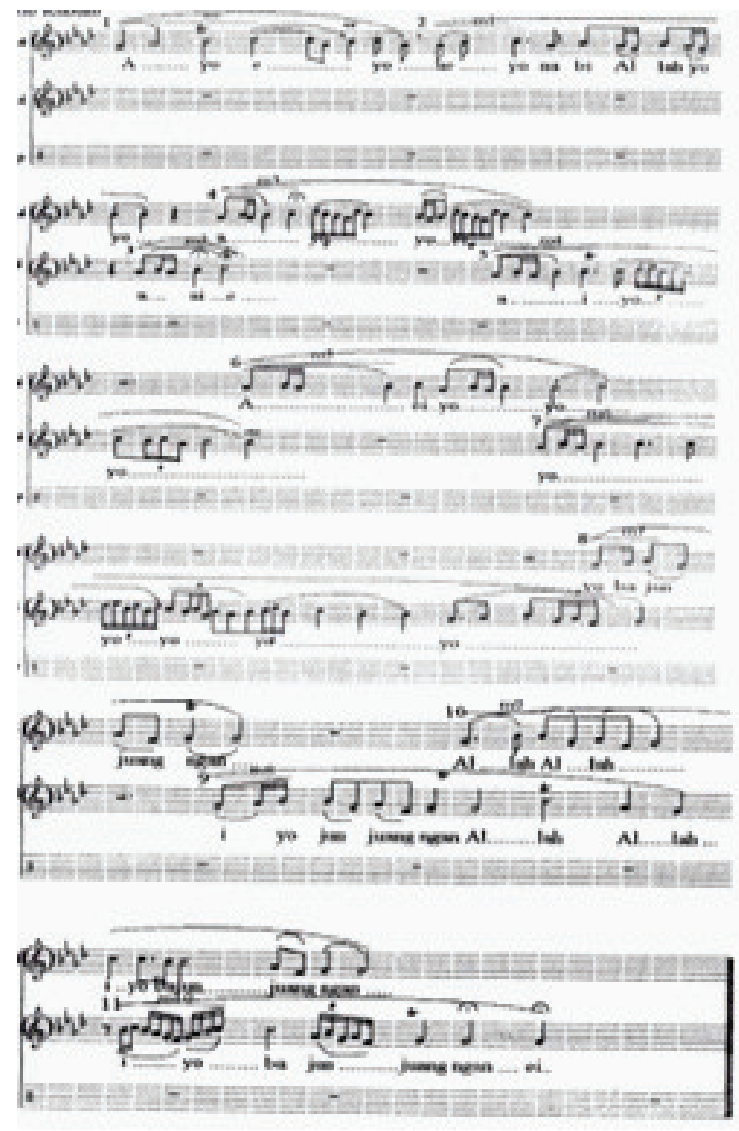

Aaaa...ei...yo...aaa...Oooo

aaaa....ei...yo... Nabi Allah ho Nabi yooo

Оooo...Oooo....Oooo....Оooo

Ааaа...ei....уо....ey....уооо

Аaаa...ei...yo....ey....yoo

Аaаa....ei....yo...oooo...Ya еeеe... Yaaaa

Ya $0000 \ldots . . .0 .0 .00$

Aaаa...ei...уо...Ya Eeеe.....Ya Aaаa

Ya Oоooo...o...o.oo

Aaаyooo...ju...unju...ngan

Aaayooo...ju...unju...ngan

Allah....Allah...

Allah....Allah...

Aaayooo...ju...unju...ngan

Aaayooo...ju...unju...ngan

Aaaaa...ei...Allah,

Allahurabbi, rabbihurabbi

Allahurabbi bak tuhan kito Nabi Muhammad

Panghulu kito,

wahai sahabat tolan saudaro

Terjemahan:

(Nabi Allah ya Nabi, pimpinan umat junjungan kita, Allahu Robbi Tuhan kita Nabi Muhammad penghulu kita, wahai sahabat teman saudara kita). 


\section{Khotbah}

Setelah imbauan khotbah dilanjutkan lagu khotbah. Bagian khotbah adalah bagian isi pertunjukan salawat dulang yang diawali dengan teks yang berisikan permintaan maaf dari tukang selawat yang ditujukan kepada masyarakat yang telah mengundang masyarakat penonton.

\section{Melodi khotbah:}

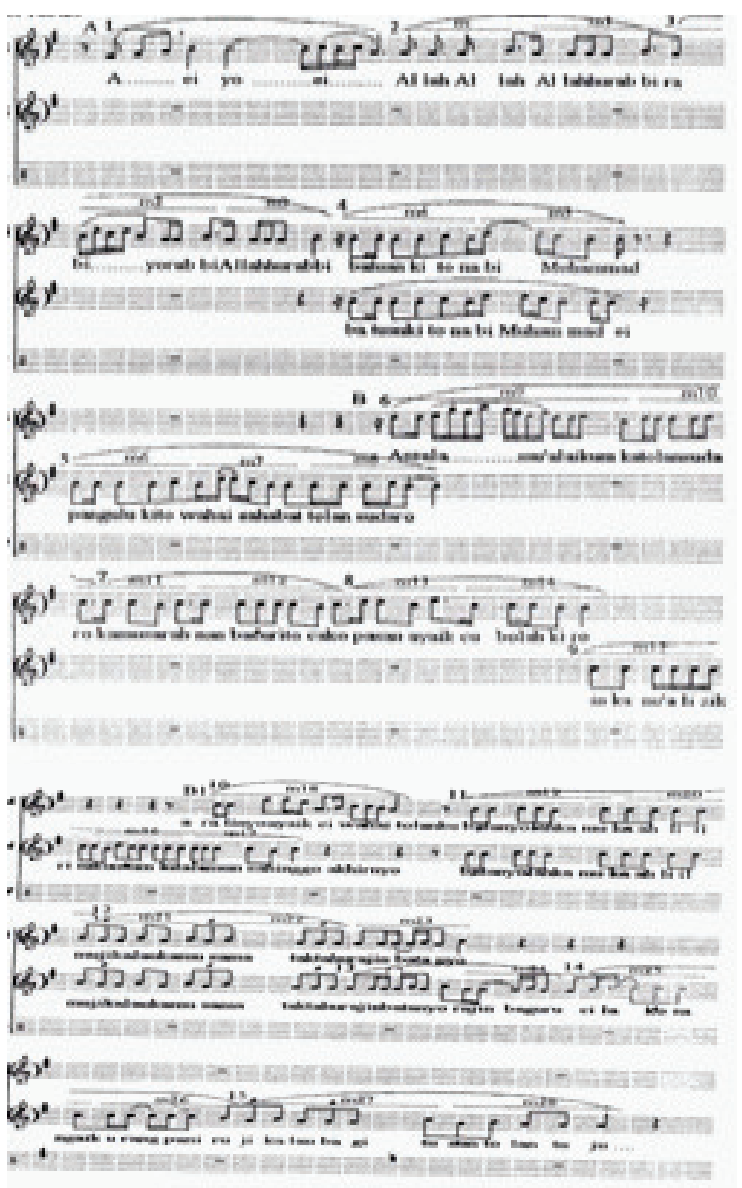

Teks khotbah:

Assalamualaikumnan kami pulangkan

Kapado sialek atau sipangkalan

Nan telah maundang ka ini jamuan

Jikok nyo jauah surek lah balayangkan

Jikok nyo dakek pinanglah bakapurkan

Sakaranglah hadir ka ini jamuan

Palaklah raso bapanitahan

Jikok nan awih lah babari aia

Jikok nan litak lah babari makan

Sekarang lah tibo pulo panitahan

Dari silang nan bapangka ka isi jamuan

Taragak di salero handak mamakan

Taragak di talingo handak mandangakan

Buruang nan jinak bak raso di tangan

Tapi dek kami salaku undangan

Pintak biaso kami palakukan
Kandak biaso kami barikan

Sabalum kandak kakami isi

Di kami kok kurang taratik jo mojilih

Nan tuo-tuo kok kurang tahormati

Nan ketek kok kurang takasihi

Nan samo gadang kok kurang terpagauli

Sabab bagitu katonyo kami

Dari nan tuo duduak agak tatinggi

Antah talinteh tabalakangi

Rilah jo maaf kami di bari

Sabuah lagi kadalam sidang

Mano sagalo alek nan datang

Nan dari jauah lah tibo nan dari ampia lah datang.

Lah baduyun-duyun katampek sakarang

Untuk menyaksikan salawaik dulang

\section{Antaro kami nan duo pasang}

Salawaik kami di umpamokan urang

Baik ibaraik balai kota Padang Panjang

Balainyo rami pagi jo patang

Bak ibaraik bendi jo kereta layang

Nyampang kok ado urang nan manompang

Walau kapai walau kapulang

Nak babendi rancak nak bakudo gadang

Kusia nyo nak matah lari nyo nak kancang

Tapi dek kami bauntuang malang

Bendinyo buruak kudo patah pinggang

Lari maniku dek panyakik jumalang

Yo bagi.....tu...... lah umpamo

\section{Terjemahan:}

(Assalamualaikum kami katakan, kepada yang punya helat (panitia acara) yang telah mengundang ke tempat pertemuan ini, dari jauh surat dikirimkan jika dekat undangan diantarkan, sekarang sudah hadir ditempat acara helat, jika haus diberi minum, jika lapar diberi makan, kemudian panitia sudah meminta kepada seniman untuk mendengarkan salawat dulang, burung yang jinak sudah rasa di tangan, tapi karena kami selaku undangan permintaan akan diberi. Sebelum kehendak akan diberi mohon maaf jika yang tua-tua kurang terhormati, yang kecil kurang terkasihi yang sama besar jika kurang terpergauli. Dari yang tua duduk agak tertinggi, jika kurang terhormati atau terbelakangi, rela dan maaf kami diberi. Satu lagi untuk semua penonton dari jauh sudah datang, untuk mendengarkan salawat dulang. Antara kami yang dua pasang, selawat kami diumpamakan orang, seperti ibarat pasar Padangpanjang yang ramai dari pagi sampai sore, ibarat kuda bendi dengan kereta layang, jika ada yang ikut naik, walau akan pergi atau akan pulang, bendi bagus kudanya besar dengan kusirnya akan berlari kencang, tetapi bagi kami nasib yang sial, bendi buruk kuda patah pinggang, jalan menunduk seperti penyakit jembalang). 


\section{Bagian lagu Batang}

Setelah lagu khotbah dilanjutkan dengan lagu batang. Teks lagu batang adalah ungkap-an yang disampaikan oleh tukang selawat dengan syair lagu yang berisikan sanjungan kepada Allah dan Rasul-Nya (Nabi Muhammad). Bagian lagu batang disajikan dengan irama lagu-lagu modern oleh tukang salawat dulang. Pada bagian pertunjukan ini irama lagu yang disajikan dapat juga melalui permintaan penonton. Sebelum masuk pada irama dan syair, lagu batang diawali dengan imbauan. Lagu ini merupakan pemberitahuan kepada penonton bahwa salawat dulang sudah dimulai.

Melodi lagu Batang:

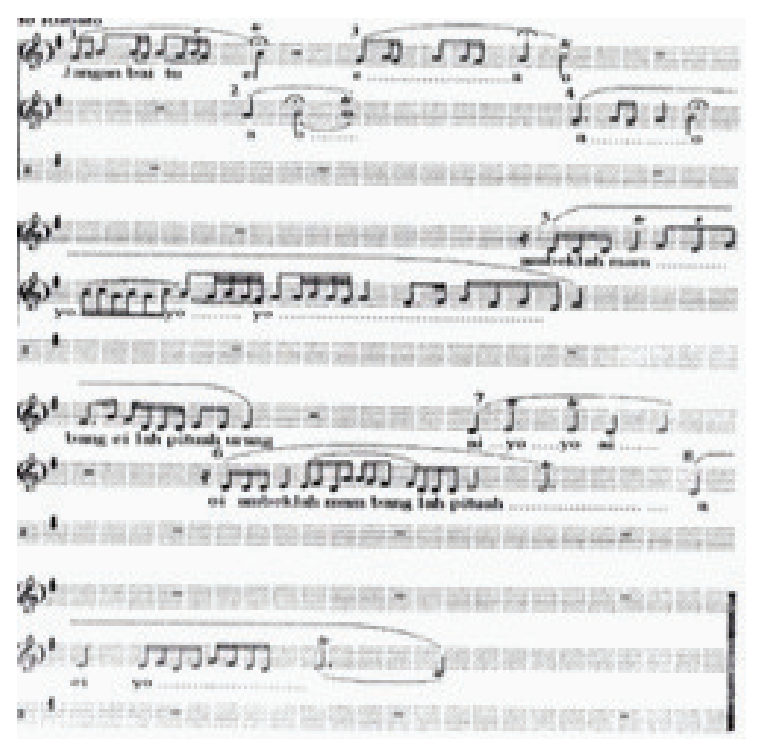

Teks Imbauan lagu Batang:

Sungguh baitu ei.... yooo...Ooo

Oooo....aaaa....Ooooo

Аaаa...уо...Oоoо...аaаa...eieiei...o.o.o

.Аaаa...уо...Ooоo...аaаa...eieiei...o.o.o

Yo dicu...bo....agak sajamang aaa...eieiei...

Yo dicu...bo....agak sajamang aaa...eieiei...

Aaaa...eieiei...oooo...ooo

Aaaa...eieiei...oooo...o.00

Terjemahan:

(Sungguh begitu dicoba juga walaupun sedikit).

Teks lagu Batang:

Aaaa...yo...Allah,ngah,ei Allah...ei...Allah

Allah Illah delai yo waa...ing. Ilallah

Iyo diya...Allah iyo...delaituanku, Hurabbi. Iyo Muhammad itu...delai urang di, imakah. Sabananyo rasul delai kulifa, Oallah. Iyo Allah
Melodi Lagu Batang

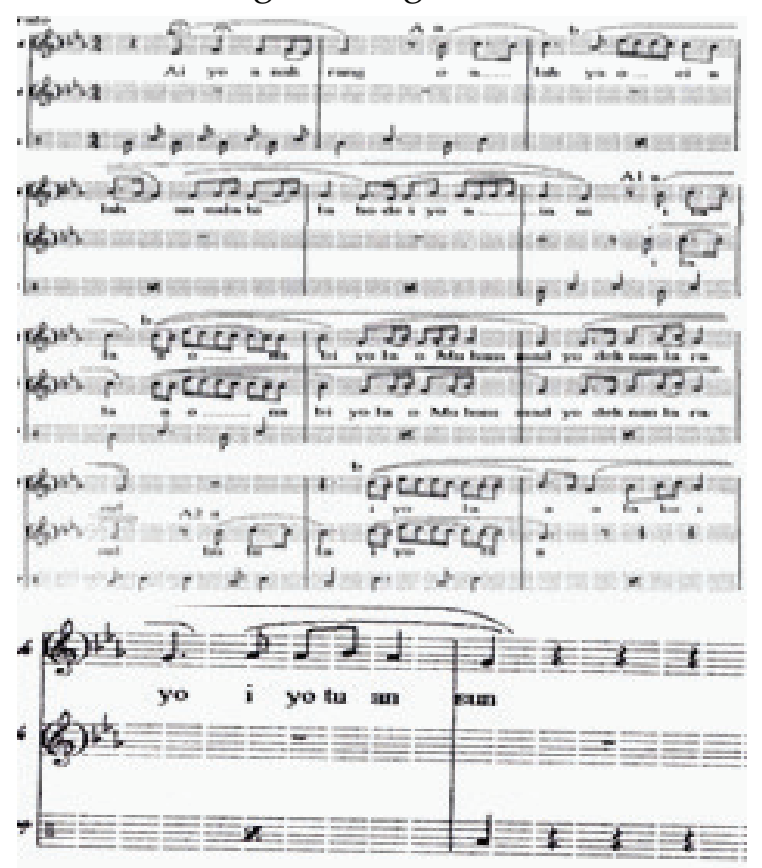

badiri delai dengan sen, dirinyo. Wakiyamuhu banafsihi deya itu si, ifatnyo. Matilah yo kamu lai didalamku, ilama. Di dalam kulimah de la Ilahaha..Ilallah

Diakui nabi masuak sarugo, Jannah

Barakaik safaat dari junjungan, kito

Lah dapek yo kami kamangambang $\mathrm{cu}$, rito. $\mathrm{Ma}$ ngambang cuirito lai dimuko ba, asamo. Sabalum kami sabuik apo-apo si, ingajo. Barilah yo maaf lai dek sidang ba, asamo. Yo deka...a.rano...nyo kami urang..aa...Alahmudomuu..do...oooo I..lallahaaa...eeeeiiii........

Terjemahan:

(Allah, ya Allah la ilaha illallah, hurobbi ya Muhammad orang Mekkah menjadi khalifah sebenarnya, Allah berdiri dengan sendirinya, wakiyamuhu binafsihi itu sifatNya, mati kamu di dalam kalimah lailahaillallah masuk sorga Jannah, berkat syafaat dari junjungan kita, sudah bisa kita bercerita untuk menyampaikan apa-apa di depan penonton bersama berilah maaf kami oleh penonton, karena kami orang masih muda).

Bagian ini diikuti dengan irama pukulan dulang sebagai pengiring lagu dengan motif, sebagai berikut.

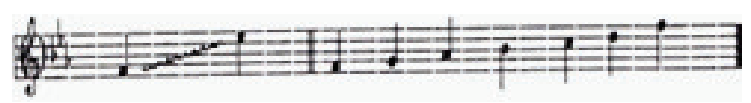

\section{Bagian lagu Yamolai}

Lagu Yamolai terdiri dari dua bagian. Bagian ini disebut dengan yamolai satu, 
artinya seniman mengucapkan kata yamolai satu kali pada setiap akhir kalimat dan yamolai dua sebanyak dua kali, sedangkan irama melodinya sama.

Melodi dan teks lagu yamolai adalah sebagai berikut.

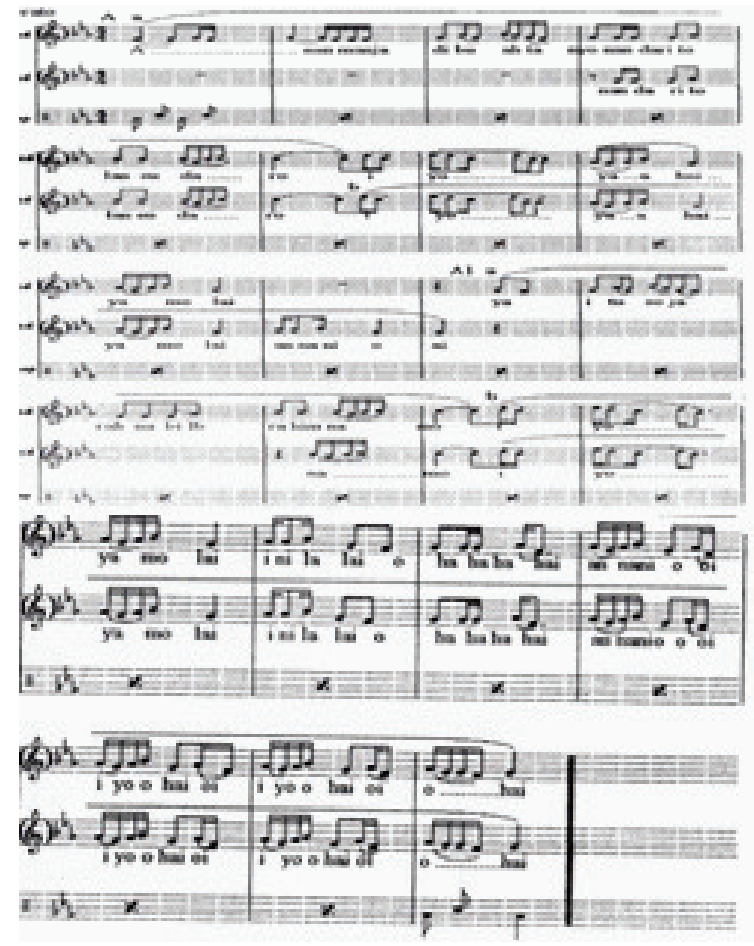

Teks lagu Yamolai I:

Aaaa...ei...Allah la Illah denan, odiyamo laillah deyamolai, annaei....

Yo Nabi Muhammad o delai ya Rasulullah ya molai. de Ilallah, anna oooo..., annanaoo, annan aеeе...,annanaooo....oooo...

Aaaa...darah nan baru de satampuak pinangnyo deyamolai, annae...eо итиа nan baru odelai satahun jaguangnyo de i lallah,annao...oooo... ееее...ehe...oooo...oooo, annanao, annanaeee......, annanao...oooo..ei...aaaa...ei...jikok tadorong delai tolonglah...elo...deya molai, annae...yo Jikok nan salah odelai tolonglahsapo de Ilallah, annanao...oooo...eеe... annanao...Anna na ееее,... Annaaao...ooooei

\section{Yamolai II}

Iyo...0000....000...Ееее...уе...00000......

Karanonyo kami kamangambang curito, de Yamolai, a Yamolai...,mangambang curitoola dimuko basamo, de ilallahAllah...Allah...aai...oooo... eеeе...annanaei...annanao...ooooo..eiei..Aaa... tarimo kasih banyak delai tarimo suko deyamolai, Ayamolai...Yo... soal pangajian delai kakami... baco,deilallah..,Allah..Allah ...aaaooo...eiee...ee... annanao...Annanae... yaeеeеi..yao...yae....aаaа ... Disoal pangajian lai dibidang agamo, deyamolai, ayamolai...
Agamo Islam odlai agamo kito, de Ilallah, Allah..Allah...aaa....Ooooo....Eeee.....annanao.. annanae...yae...yao...yaa......

\section{Terjemahan:}

(Allah ya Allah yamolai ya Nabi Muhammad ya rasulullah yamolai, darah yang baru setampuk pinang dan ilmu yang baru setahun jagung yamolai, jika terdorong tolong ditarik ke belakang, jika salah tolong tegur yamolai, karena kami akan memulai bercerita di depan penonton bersama yamolai, terimakasih banyak atas kesediaannya. Soal pengajian yang akan kami baca di bidang agama yamolai agama islam agama kita).

Untuk lagu Yamolai II, kata-kata yamolai diucapkan dua kali.

b. Bentuk penyajian dalam Bentuk Hiburan Setelah lagu Yamolai maka dilanjutkan dengan lagu Cancang. Dalam lagu Cancang inilah adanya perubahan dan ketertarikan penonton salawat dulang. Seniman salawat dulang menampilkan kehebatan dalam pertunjukan, dan juga penilaian penonton terhadap dua grup salawat dulang yang sedang bertanding. Lagu Cancang merupakan hiburan yang menyajikan irama lagu-lagu popular yang tren saat sekarang.

Pada pertunjukan lagu Cancang ini ditandai dengan lagu-lagu modern yang tren masa sekarang, seperti dangdut, pop, Minang, kasidah dan sebagainya. Lagu tersebut dinyanyikan seperti irama aslinya. Kadangkala teks nyanyinya diganti dengan kata-kata lain. Tujuannya, agar penonton bersorak, tertawa karena seniman menyanyikan lagulagu yang disukai oleh penonton.

Penggantian kata-kata tersebut tidak menghilangkan nilai-nilai ketradisiannya. Pada bagian lagu Cancang, penyaji salawat dulang dapat mengadopsi jensi-jenis irama lagu modern lainnya mulai pop, dangdut, India, lagu batak, dan sebagainya. Dengan menghadirkan jenis-jenis irama lagu tersebut, penonton mejadi lebih tertarik karena tukang salawat dulang dapat menyajikan irama lagu-lagu yang sedang populer saat sekarang. 


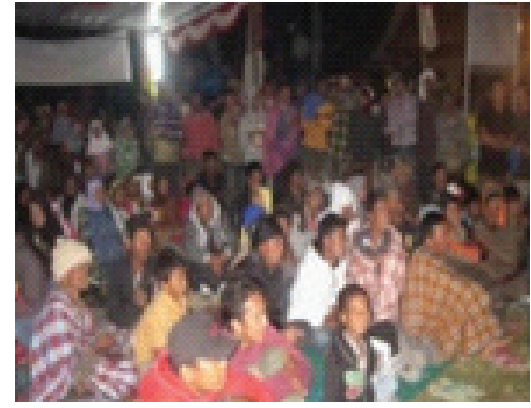

Gambar 2. Penonton salawat dulang (Sumber: Syafniati, 20 Juni 2018 di Kabupaten Solok)

Pada saat tukang selawat menyajikan lagu-lagu yang sedang tren, kadang-kadang teksnya mereka ganti dengan kata-kata lain yang disesuaikan dengan gaya salawat $d u$ lang. Namun, penonton tetap bersemangat dan menyukainya sehingga bukan saja yang kaum tua, tetapi para remaja pun tetap bersemangat, kadang-kadang sampai bersorak. Dengan demikian suasana pertunjukan semakin bergairah (lihat gambar 2).

Lagu Cancang merupakan salah satu lagu salawat dulang yang bertujuan untuk menghibur penonton. Di dalam lagu tersebut, terdapat kumpulan irama lagu-lagu modern yang syairnya kadangkala disajikan sebagaimana aslinya, dan juga dapat diganti dengan kata-kata lain. Tujuannya untuk membuat penonton tertawa.

Pengembangan musik tradisi merupakan modifikasi sebuah produk seni yang sudah ada (Elina, 2018: 312). Perkembangan pada seni tradisi salawat dulang adalah akibat terjadinya perkembangan dalam kehidupan masyarakat sejalan dengan perkembangan zaman.

Sebagai salah satu kegiatan kebudayaan, seni tidak dapat dipisahkan dengan masyarakat tempat seni itu berkembang. Hal itu merupakan bagian yang integral dari sistem sosial budaya sebuah masyarakat. Seperti yang dikemukakan oleh Irdawati (2018: 224) bahwa kesenian mempunyai sifat yang selalu berkembang karena kesenian merupakan kegiatan bergerak. Perkembangan kesenian tersebut terjadi melalui kreativitas, perubahan, peningkatan, dan penemuan baru yang selaras dengan perkembangan kehidupan masyarakat lingkungannya.

Selain itu, teks yang dinyanyikan liriknya dengan kata-kata yang mengandung humor, dan juga kalimat-kalimat lagu digubah dengan kata-kata humor yang dapat memancing tawa penonton. Teks la-gu dapat saja diganti dengan kalimat lain dalam bahasa Minang, Jawa, India, Cina, dan lagu-lagu modern yang sedang tren lainnya

Pada bagian modifikasi inilah, lagulagu populer dan modern ditampilkan oleh tukang selawat. Secara umum, humor yang ditampilkan oleh tukang salawat adalah humor yang berbentuk verbal, yaitu melalui kata-kata mendendangkan lagu yang tengah populer di tengah-tengah masyarakat dengan menggubah liriknya.

Contoh teks lagu humor:

Kini sambia bakandak irama dibuek juo, jo irama pop iko namonyo, irama dangdut lai jadi juo, irama Minang indak lo lupo, Jawa jo Sunda dibari pulo.

Terjemahan:

(Sekarang sambil meminta irama dibuat juga, dengan irama pop ini namanya, irama dangdut jadi juga,irama minang tidak lupa, Jawa dengan Sunda diberi pula)

Hal ini dapat diungkapkan melalui humor, cemooh, dan kata sindiran, baik yang ditujukan terhadap penonton maupun terhadap sesama tukang selawat. Salah satu bentuk teks lagu pada struktur lagu Cancang:

Ikolah lagu dari kami baduo, untuak panjagokan mato, jo irama dangdut atau jo irama pop nyo, jo lagu India atau rook jadi juo.

\section{Terjemahan:}

(Inilah lagu dari kami berdua, untuk membangunkan mata dengan irama dangdut atau dengan irama lagu pop atau dengan lagu India, irama lagu rock bisa juga ataupun irama lagu Minang kami pun bisa).

Untuk lebih jelasnya lihat salah satu teks lagu dangdut yang disajikan pada pertunjukan selawat oleh Grup Sinar Barapi 
yang membawakan lagu Dikaja Jando, yang dipopulerkan oleh Mak Itam dan Mak Lepoh berikut.

Dangakan malah Mak Itam nde nan bakato, Mak Itam rancak onde mak urang kayo rayo, Awak lai tampan la Mak Itam banyak harato, Sayang saketek la Mak Itam babini jando. Mak Itam gapuak urangnyo gadang salero, Mak Itam ompong giginyo. Onde Mak Lepo la Mak Lepo dengarkan malah Titititiw... Titititiw...

\section{Terjemahan:}

(Dengar mak Hitam saya berkata, mak Hitam ganteng kaya raya dan banyak harta, tetapi sayang mak Hitam punya istri janda dan mak Hitam gemuk tapi ompong giginya).

Dalam rangka melestarikan kesenian salawat dulang, terdapat dua jenis teks yang harus dikuasai oleh seniman. Yaitu, teks yang harus dihafalkan yang berisi tentang ajaran agama; dan teks yang harus dicari sendiri melalui irama lagu-lagu modern.

Perkembangan salawat dulang juga merupakan salah satu usaha untuk pelestarian budaya yang dilakukan oleh senimannya dengan tujuan mempertahankan warisan budaya masyarakat Minangkabau. Pelestarian merupakan suatu cara dalam membuat sesuatu berkelanjutan. Keberlanjutan seni tradisi terletak kepada proses pewarisan terhadap generasi.

Menurut Dewi, keberlanjutan dilakukan dengan cara pembinaan terhadap generasi sebagai pewaris. Pembinaan dan pengembangan ini dilakukan para pekerja seni, sedangkan masyarakat dapat memberi dukungan (2016: 145).

Saat ini, pertunjukan salawat dulang telah berubah semenjak masuknya pengaruh teknologi dalam seni pertunjukan, seperti musik-musik modern. Kesenian salawat dulang semakin hari semakin bekembang sehingga dapat dinikmati oleh masyarakat Minangkabau. Perubahan sebuah kesenian itu berupa suatu modifikasi yang terjadi dalam perangkat gagasan-gagasan yang disetujui secara sosial oleh sekelompok masyarakat tertentu (Rohidi, 2000: 213).
Masuknya budaya luar tersebut membuat pertunjukan salawat dulang diminati oleh kalangan tua, muda, ibu-ibu, dan anak-anak. Lagu-lagu modern, seperti pop, dangdut, dan religi yang terdapat pada lagu Cancang sudah menjadi bagian terpenting dalam pertunjukan salawat dulang. Adapun lagu-lagu yang ditampilkan diutamakan lagu-lagu yang sedang tren di tengah masyarakat. Dalam hal ini, Sriwulan mengemukakan bahwa,

The introduction of popular culture (music) in the performance of salawaik dulang is an indication of an aesthetical "battle" between two ideologies. One side is an ideology containing Islamic values and the other is popular culture packaged in various musical forms and rhythms, performed tosuit the tastes of the audience (2018: 47).

(Dengan masuknya budaya musik populer dalam pertunjukan salawaik dulang, menunjukkan adanya indikasi "pertarungan" dua ideologi secara estetis. Satu sisi berada dalam idiologi yang mengandung nilainilai islami dan pada sisi lain ada budaya populer yang dikemas dengan berbagai macam irama musik, disajikan untuk memenuhi selera penggemarnya).

Hal demikian dapat menjadi salah satu faktor penyebab terjadinya perkembangan seni tradisi yang ada. Perkembangan ini sejalan dengan perkembangan teknologi, seperti radio, TV, telepon genggam (handphone), sosial media, dan internet untuk mendengarkan lagu-lagu modern. Hal ini seperti dikatakan Minarti bahwa pengaruh budaya luar, seperti ilmu pengetahuan, teknologi, transportasi, dan seni modern, telah masuk dalam kehidupan masyarakat dan telah dijadikan sebagai modal yang harus dikelola, diciptakan dan menjadikan sumber kesejahteraan baru bagi mayarakatnya (2018: 347).

Musik populer adalah produk budaya (dalam bentuk nyanyian/lagu) yang disukai banyak orang karena kebutuhan estetis dan mudah dipahami. Musik populer adalah sesuatu yang menyenangkan dan disukai oleh banyak peminat dengan 
penekanannya pada sifat hiburan, seperti dalam pertunjukan lagu Cancang yang merepresentasikan ideologi musik populer dan juga estetika modern, seperti irama musik dangdut, lagu Minang standar, musik India, dan lain-lain. Arjuna Minang, misalnya, mengatakan bahwa lagu Cancang dapat dibagi berdasarkan situasi dan kondisi pertunjukan, yaitu: (a) permintaan penonton bersama; (b) pertanyaan rekan sesama grup salawaik; dan (c) alasan menyambung cerita (Wawancara tanggal 17 Juni 2018 di Lintau).

Perkembangan salawat dulang dari waktu ke waktu melalui berbagai proses, pada umumnya mengikuti proses perubahan yang terjadi dalam kebudayaan suatu masyarakat.

Perubahan itu dapat diakibatkan oleh pertumbuhan masyarakat dengan segala prasarana dan kebutuhan seniman (Sedyawati, 1981: 5). Perubahan yang terjadi pada salawat dulang sekarang ini diterima oleh masyarakat pendukungnya, bahkan dianggap sebagai suatu perkembangan yang positif, karena tidak bertentangan dengan ajaran agama dan adat istiadat yang berlaku.

Secara filosofis, masyarakat Minangkabau juga menyadari bahwa dalam kebudayaan, perubahan adalah sesuatu yang tidak mungkin ditolak, karena merupakan nilai dasar dari budaya orang Minangkabau. Perubahan-perubahan yang terjadi dalam pertunjukan salawat dulang, merupakan suatu perkembangan untuk memperbaharui serta mempertahankan kehidupan salawat dulang dalam menghadapi tantangan zaman. Ada dua jenis perkembangan yang terjadi dalam pertunjukan salawat dulang, yaitu kuantitatif dan kualitatif. Perekembangan secara Kuantitatif itu adalah mengembangkan seni pertunjukan tradisional dengan membesarkan volume penyajiannya, meluaskan wilayah pengenalannya. Sedangkan kualitas suatu karya seni ditentukan oleh

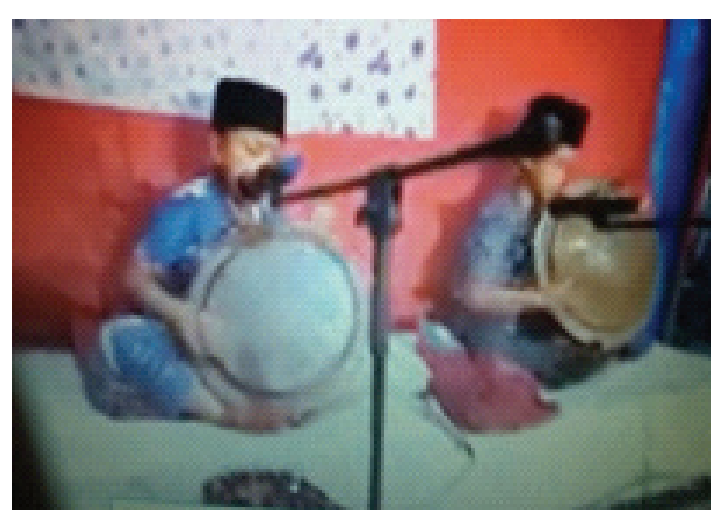

Gambar 3. Grup Bintang Cilik (sumber: http:// m.youtube.com diakses 02-08-2018)

adalah usaha-usaha untuk menciptakan karya baru. Usaha perluasan haruslah dipandang sebagai prasarana, sedang tujuan terakhir adalah memperbesar kemungkinan menciptakan karya-karya yang berarti bagi masyarakat.

Perkembangan kesenian salawat dulang dari segi kuantitas adalah terjadinya perambahan grup, seperti Arjuna Minang, Sinar Berapi, Langkisau, Alang Babega, Panah Arjuna, Jet Angkasa Apolo II, DC Delapan, Piring Talayang, Peluru Kendali, dan sebagainya. Semua grup salawat dulang ini merupakan grup yang digemari masyarakat, dan sering tampil pada di berbagai daerah Minangkabau. Selain itu, saat ini terdapat grup cilik binaan dari Sinar Barapi, yang diberi nama Bintang cilik (bintang kecil). Grup ini ditampilkan oleh anak-anak yang masih berusia berkisar 13 tahun.

Grup salawat dulang anak-anak tersebut merupakan salah satu implementasi kecintaan anak-anak terhadap kesenian tradisi yang semakin dihargai oleh masyarakat pendukungnya.

Adapun pengembangan dari segi kualitas adalah tempat pertunjukan dan perubahan fungsi. Pertunjukan salawat dulang pada masa sekarang lebih dominan berfungsi sebagai hiburan. Walaupun unsur agama Islam yang ada tetap dipertahankan agar kesenian menyesuaikan diri dengan perkembangan zaman. 


\section{Lagu-lagu Modern yang Diadopsi pada Pertunjukan Salawat dulang}

Dalam penyajian salawat dulang, lagulagu modern telah menjadi salah satu struktur yang harus hadir dalam pertunjukan. Dengan adanya irama lagu-lagu modern, maka salawat dulang dapat berkembang dan menyesuaikan dengan selera penonton. Namun, dalam pertunjukan salawat dulang, teks lagu-lagu modern yang diadopsi tersebut tidak disajikan secara utuh, melainkan berupa penggalan-penggalan melodinya saja, kemudian dinyanyikan dengan versi dan gaya salawat dulang.

Adapun teks yang diganti dengan syair, yang dibuat secara spontan oleh penyaji, sesuai dengan situasi penonton, bisa saja bersifat cemooh atau humor, dengan tujuan untuk membuat penonton menjadi terhibur. Lagu-lagu modern tersebut hanya diiringi oleh pukulan salawat $d u-$ lang. Sebagai tambahan musiknya, seniman menjadikan vokal sebagai illustrasi musik tambahan. Yang lebih menarik lagi, penyaji salawat dulang dapat membangun suasana penonton menjadi tertawa dan bersorak. Inilah salah satu usaha seniman salawat dulang untuk mempertahankan keberlangsungan kehidupan kesenian tradisional agar selalu eksis di tengah-tengah masyarakat Minangkabau.

Perubahan yang terjadi dalam pertunjukan salawat dulang merupakan suatu kemajuan, dan berdampak pada perkembangan budaya setempat, baik internal maupun eksternal. Musik modern terlahir karena adanya budaya modern yang pada umumnya berorientasi pada kebudayaan populer dan yang sudah mendapatkan banyak pengaruh dan sentuhan lain, mulai dari alat instrumennya sampai bentuk penyajiannya.

Bagaimana agar salawat dulang mendapatkan perhatian dari masyarakat sebagaimana kesenian lain? Masyarakat mempunyai peranan penting dalam kehidupan sebuah pertunjukan kesenian.

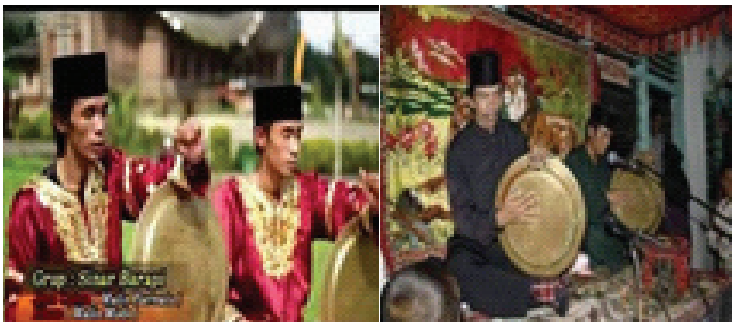

Gambar 4. Kostum Tukang Selawat sekarang.

(sumber: http://id.m.wikipedia.org/wiki/selawat diakses 03-10-2017)

Perubahan internal pada salawat dulang dilihat dari bergesernya fungsi menjadi hiburan dengan menghadirkan lagu-lagu modern, seperti dangdut, pop, Minang, India, Jawa, lagu Sunda, dan sebagainya.

Berikut adalah contoh teks lagu Batak yag disajikan oleh grup Langkisau.

Butet.... dipangungsian do amang mu ale butet, Damarguilla da mardarurat ale butet, Damarguilla da mardarurat ale butet Butet.. tibo do mulak au amang ale butet Musuttai ikkon saut do talu ale butet

Musuttai ikkon saut do talu ale butet

i..doge doge doge $i$ doge $i$ doge doge

i..doge doge doge $i$ doge $i$ doge doge

Teks lagu Butet tersebut dinyanyikan dengan gaya salawatdulang. Kadang-kadang suaranya sumbang dan kadang-kadang diganti dengan kata-kata humor sehingga memancing penonton tertawa. Inilah yang menjadi ciri khas pembeda salawat dulang masa sekarang. Masyarakat pun semakin menyukai kesenian ini, sehingga salawat dulang dicintai masyarakat Minangkabau.

Perkembangan dan perubahan yang terdapat pada selain lagu-lagu dalam pertunjukan selawat, kostum yang dipakai oleh seniman salawat dulang juga telah diganti. Semula, seniman salawat dulang memakai baju kemeja dan celana warna hitam, maka sekarang kostum pemusik sudah diganti dengan kostum untuk pertunjukan kesenian.

Perubahan eksternal dapat dilihat dari perkembangan grup-grup salawat dulang, 
tempat pertunjukan, kostum pemain, dan sebagainya (lihat gambar 4).

Salah satu lagu yang diadopsi dalam penyajian salawat dulang adalah lagu kasidah rebana yang berjudul Perdamaian.

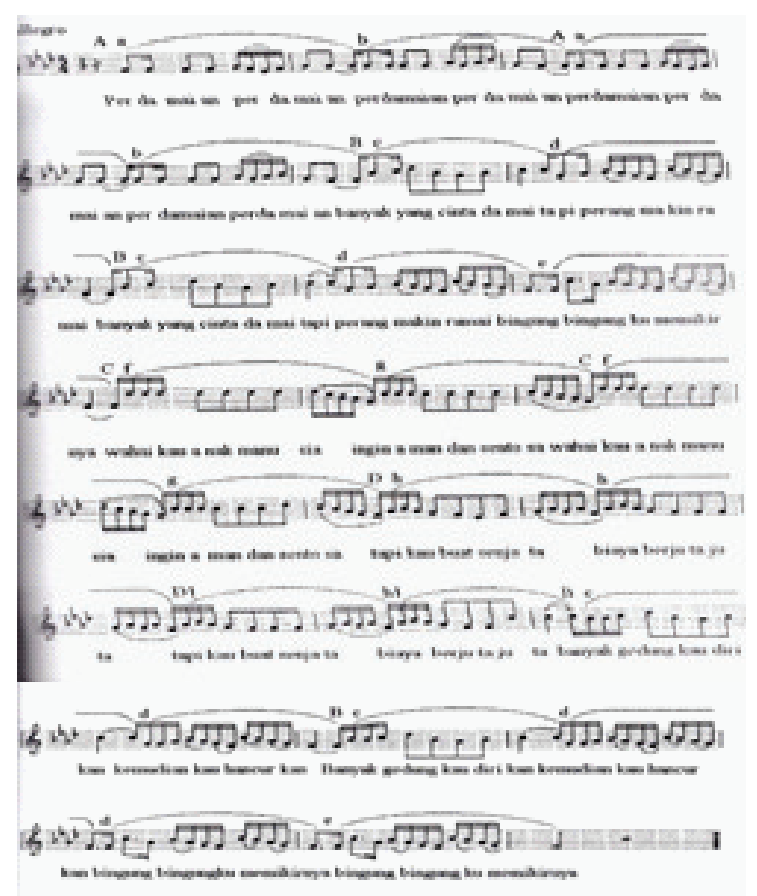

Berikut adalah teks lagu Perdamaian.

Perdamaian perdamaian $2 \mathrm{x}$

Banyak yang cinta damai

Tapi perang makin ramai

Banyak orang cinta damai

Tapi perang makin ramai

Bingung bingung ku memikirnya

Wahai kau anak manusia

Ingin aman dan sentosa

Wahai kau anak manusia

Ingin aman dan sentosa

Tapi kau buat senjata

Biaya berjuta juta

Tapi kau buat senjata

Biaya berjuta juta

Banyak gedung kau dirikan

Kemudian kau hancurkan

Banyak gedung kau dirikan

Kemudian kau hancurkan

Bingung bingung ku memikirnya

Lagu Gubuk Derita (dangdut)

Teks:

Aku rela walau hidup susah

Aku rela walau menderita

Asalkan kau sayang asalkau setia

Pagi makan sore tiada

Tak kan pudar sayang ku padamu

Walau hidup ini di gubuk derita

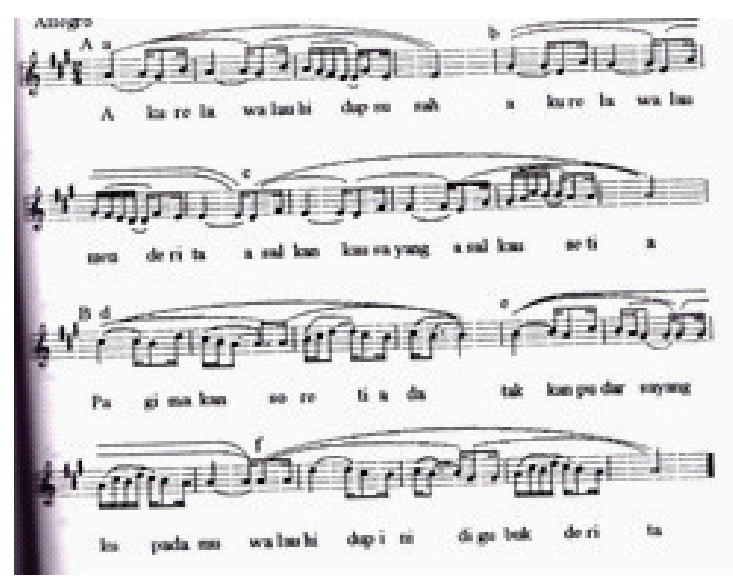

Melodi lagu Gubuk Derita dinyanyikan sesuai teks asli. Kemudian, dalam penggarapan teks lagu tersebut diganti dengan versi salawat dulang. Contoh teks lagu dangdut.

Katanya... Cuma aku yang kau sayang

Katanya... Cuma aku yang kau sayang

Besarnya gunung tak sebesar hatiku

Terangnya bulan tak seterang jiwaku

Disaat engkau bisikan.....

Cuma akulah yang kau cinta

Melati yang ku semaikan

Penuh kasih sayang

tiada berkembang

Begitulah cintaku pada dirimu

Putus dijalan...mengapa...

ho...ho...ho...

\section{Contoh lagu Minang:}

Lah naiak sijando mudo gali pinggang digalitiaknyo

Rem dipijak bola mandayo

Pitih dimintak nyo ago-ago

Pikiran kacau talantak oto

Sia bana nan taniayo

Tukang ojek...

Terjemahan:

(Sudah naik janda muda, geli pinggang digelitiknya, rem dipijak bola hidup, uang diminta ditawar-tawarnya, pikiran galau akhirnya tertabrak mobil, akhirnya siapa yang sengsara... tukang ojek)

\section{Faktor Penyebab Terjadinya Perubahan Pertunjukan Salawat Dulang}

Kesenian tradisional yang semula melekat dengan adat dan agama cendrung dikembangkan menjadi kesenian tontonan, dan bahkan sebagai propaganda. Ikatanikatan estetis antara elemen-elemen tradisional dalam kebudayaan baru menuju 
budaya populer yang modern bagaikan peristiwa perlawanan budaya yang sulit diantisipasi.

Kemajuan teknologi dan komunikasi juga telah menembus sendi-sendi kehidupan masyarakat di nusantara dalam mempermudah hubungan dengan dunia luar. Terjadilah pergeseran-pergeseran nilai yang mengakibatkan perubahan menuju suatu perkembangan. Selanjutnya, perkembangan tersebut dapat menghilangkan nilai-nilai yang melekat pada tradisi seperti nilai adat dan agama sebagaimana yang terjadi pada salawat dulang.

Kehadiran teknologi dalam kehidupan sosial budaya masyarakat termasuk dalam seni pertunjukan menjadi pendorong utama dalam perkembangan kesenian tradisional. Seniman salawat dulang selalu mencari dan mempelajari jenis lagu-lagu modern yang lagi tren di tengah masyarakat, seperti lagu India, Cina, Arab, atau lagu-lagu yang disenangi oleh semua kalangan masyarakat. Lagu-lagu modern tersebut disajikan dalam pertunjukan selawat. Oleh sebab itu, perubahan terjadi ada kalanya berawal dari perbuatan personal atau mungkin dari sekelompok pendukung baik sebagai penemu (innovator) maupun sebagai pemakai (user). Keterlibatan masyarakat dalam perubahan pada kategori pertama dapat dipandang sebagai subjek, sedangkan dalam ketegori kedua sebagai objek dalam perubahan tersebut (Bahar 2004: 30).

Menyikapi perkembangan salawat dulang, masyarakat seniman dan tokoh pemerintah selalu mengambil inisiatif agar kesenian ini bisa berkembang di tengah masyarakat. Untuk melihat lagu-lagu yang dianggap tren di masa sekarang, Holt dalam Rustiyanti, (2010: 17), menyebutkan bahwa unsur-unsur baru dalam budaya merupakan rangkaian kesatuan pertumbuhan budaya, tidak berarti unsur-unsur budaya yang ada sebelumnya menghilang. Kehidupan budaya akan selalu mengalami proses akultur- asi, dengan munculnya sebuah karya baru. Akulturasi merupakan proses yang dilakukan satu kelompok manusia dengan satu kebudayaan tertentu mengalami pergeseran nilai. Pengaruh kebudayaan asing lambat laun diterima dan diolah ke dalam kebudayaan sendiri tanpa menyebabkan hilangnya kepribadian itu sendiri.

Secara sosiologis, perubahan suatu masyarakat merupakan fenomena yang bisa terjadi disebabkan oleh beberapa hal dalam kehidupan masyarakat sehari-harinya. Perubahan yang terjadi pada salawat dulang dapat dilihat dari faktor ekternal dan internal.

1. Faktor Eksternal

Faktor eksternal adalah faktor yang mempengaruhi perkembangan yang disebabkan adanya pengaruh dari luar. Faktor eksternal memandang jika terjadi persentuhan (kontak) antara dua kesenian atau lebih dalam waktu tertentu, unsur kesenian yang kuat akan mempengaruhi kesenian yang lemah. Faktor-faktor tersebut antara lain adanya pengaruh budaya asing. Budaya asing seperti adanya akulturasi dan difusi (Setiadi, 2011: 159).

Selain adanya pengaruh yang disebabkan oleh percampuran dua budaya atau lebih, salawat dulang juga dipengaruhi oleh beberapa unsur yang datang dari luar daerah. Kemudian, pembauran tersebut menjadi satu dan melahirkan bentuk baru. Pertunjukan salawat dulang sekarang ini sudah dikenal oleh masyarakat di hampir semua daerah di Minangkabau, kecuali Pasaman (Wawancara dengan seniman salawat $d u$ lang, Arjuna Minang, 24 Juni 2018 di Kayu Tanam).

2. Faktor Internal

Faktor internal adalah pengaruh yang datang dari dalam, berupa konflik yang terjadi dalam karena persaingan sesama seniman selawat. Untuk mencari simpati dan empati masyarakat terhadap pertunjukannya, maka seniman lebih kreatif dalam mempelajari lagu-lagu terbaru dan selalu 
menjaga hubungan baik. Para seniman berpacu untuk meraih hal itu dengan selalu bersemangat dan berusaha meningkatkan keterampilan dalam pertunjukan. Hal ini dilakukan dengan menyajikan lagu-lagu yang terbaru untuk dimasukkan dalam penyajian salawat dulang. Seniman salawat dulang yang tidak mau mengikuti perkembangan maka grup selawat tersebut tidak akan diminati masyarakat. Maka, dengan sendirinya grup tersebut akan mati, karena kurangnya peminat. Selain itu, ada juga grup selawat yang mengganti pasangan karena dianggap tidak cocok. Misalnya, karena tidak dapat menguasai lagu-lagu terbaru yang mengakibatkan grup selawat tersebut kurang diminati masyarakat.

Untuk mempertahankan kehidupan grup selawat, ada tiga hal yang dilakukan oleh seniman salawat dulang. Pertama, mengadakan kontak dengan sesama seniman. Melalui apresiasi terhadap karya orang lain, seseorang dapat belajar untuk kreatif dalam menciptakan bentuk baru. Bentuk baru tersebut digarap dan disesuaikan dengan situasi dan kondisi masyarakat. Salah satu yang telah dilakukan oleh seniman salawat dulang. Kedua, mengadopsi lagu-lagu yang dianggap lebih maju dari kesenian yang telah ada, dengan cara memasukkan unsurunsur musikal kesenian tersebut dalam salawat dulang. Pengadopsian lagu-lagu tersebut telah membawa perubahan dalam bentuk baru dan dapat diterima oleh masyarakat sehingga dapat menarik minat penonton.

Ketiga, memberikan kebebasan terhadap sesama seniman salawat dulang dalam mengekspresikan kemampuan dan melahirkan bentuk-bentuk variasi dengan gayanya masing-masing.

\section{SIMPULAN}

Kesenian salawat dulang sekarang telah banyak mengalami perkembangan dan perubahan. Awalnya, sebagai syiar agama Islam berupa kalimat-kalimat zikir, yang berisi sifat Allah Swt. yang dikenal dengan sifat dua puluh, yang dihapalkan secara bersama-sama dengan cara dilagukan. Gunanya sebagai tontonan dan hiburan.

Pertunjukan salawat dulang mengalami perubahan disebabkan faktor internal dan ekternal. Faktor internal adalah perubahan terhadap bentuk dan struktur pertunjukan salawat dulang. Faktor ekternal adalah terjadinya pergeseran fungsi dari dakwah menjadi seni pertunjukan.

Perkembangan salawat dulang merupakan salah satu upaya untuk menghidupkan dan melestarikan kesenian tradisional dalam budaya masyarakat Minangkabau.

Seni pertunjukan salawat dulang mempunyai struktur yang terdiri atas imbauan khotbah, khotbah, yamolai I dan yamolai II, lagu Batang, dan lagu Cancang.

\section{Ucapan Terimakasih}

1. Ucapan terima kasih disampaikan kepada Rektor ISI Padangpanjang yang telah memberikan fasilitas berupa surat tugas penelitian ke Kabupaten Tanah Datar, kota Solok, dan Padangpariaman kepada peneliti untuk dapat melaksanakan penelitian ini.

2. LPPMPP ISI Padangpanjang yang telah memberikan bantuan pada peneliti dalam urusan administrasi penelitian.

3. Seniman salawat dulang yang telah bersedia dijadikan sebagai objek penelitian sehingga dapat memberikan informasi melalui wawancara tentang segala sesuatu yang berhubungan dengan salawat dulang.

\section{Daftar Pustaka}

Atjeh, A. B. (1963). Pengantar Ilmu Tarekat Uraian Tentang Mistik. Jakarta: Ramadhani.

Bahar, M. (2004). Seni Tradisi Menantang Perubahan. Bunga Rampai. STSI Padangpanjang.

Dewi, H. (2016). Keberlanjutan dan Perubahan Seni Pertunjukan Kuda Kepang di Sei Bamban, Serdang Beda- 
gai, Sumatera Utara. Panggung, 26 (2), 139-150.

Elina, M. (2018). Pengemasan Seni Pertunjukan Tradisional sebagai Daya Tarik Wisata di Istana Basa Pagaruyung. Panggung, 28 (3), 304-316.

Esten, M. (1993). Minangkabau, Tradisi, dan Perubahan. Padang: Angkasa Raya.

Firdaus. (2013). Salawat Dulang. Buku Ajar. ISI Padangpanjang.

Irdawati. (2018). Pengembangan Koreografi Tari Podang Perisai dari Tradisi menjadi Modern di Kuantan Singingi Riau. Panggung, 28 (2), 215-229.

Minarti, R. (2018). Kreativitas Garap sebagai Strategi Pengembangan Musik Kompang Grup Delima di Bantan Tua Bengkalis. Panggung, 28 (3), 346-359.

Moleong, L. J. (1991). Metode Penelitian Kualitatif. Bandung: PT Remaja Rosda karya.

Ricklefs, M. C. (1995). Sejarah Indonesia Modern. Yogyakarta: Gajah Mada University Press.

Rohidi, T. R. (2000). Kesenian dalam Pendekatan Kebudayaan. Bandung: Sunan Ambu Press.
Rustiyanti, S. (2010). Menyingkap Seni Pertunjukan Etnik di Indonesia. Bandung: Sunan Ambu Press.

Setiadi, E. M. (2011). Ilmu Sosial Budaya dan Dasar. Jakarta: Kencana.

Sedyawati, E. (1981). Pertumbuhan Seni Pertunjukan Indonesia. Jakarta: Sinar Harapan.

Soedarsono R. M. (2001). Metodologi Penelitian Seni Pertunjukan dan Seni Rupa. Bandung: Masyarakat Seni Pertunjukan Indonesia (MSPI).

Sriwulan, W. (2018). Spirituality in The "Battle" of Two Ideologies in The Performance of Salawaik Salawat Dulang in Minangkabau. Jurnal Arts and Design Studies, 67, 145-155.

(1999). Salawat dulang Seni Bernafaskan Islam Salah Satu Ekspansi Budaya Masyarakat Minangkabau (Kontinuitas dan Perubahan). Tesis S2. UGM Yogyakarta.

Syani, A. (1995). Sosiologi dan Perubahan Masyarakat. Jakarta: Pustaka Jaya.

Yunus, M. (1985). Sejarah Pendidikan Islam Jilid III. Jakarta: Departemen Pendidikan dan Kebudayaan. 